\title{
Coronavirus (COVID-19) and the Survival of Small and Medium Enterprises in Abeokuta, Ogun State Nigeria
}

Shodiya Olayinka Abideen"

Department of Business \& Finance, Crescent University, Abeokuta, Nigeria

DOI: $10.36347 /$ sjebm.2020.v07i06.002

| Received: 12.06.2020 | Accepted: 20.06.2020 | Published: 26.06.2020

*Corresponding author: Shodiya Olayinka Abideen

Abstract

Original Research Article

This study assessed the relationship between COVID-19 and the survival of Small and Medium Enterprises. The survey research design was employed in carrying out the study and SMEs owners in Abeokuta, Ogun State, Nigeria constituted the population. The study used the Yamane formula for calculating sample size to derive a total of 261 SMEs as the sample size for this study. Data for the study was collected using a standardized questionnaire and the collected data was analyzed using inferential statistics (regression analysis and correlation analysis). The result of the analysis unveiled those COVID-19 sub-variables (lockdown days, internal movement restriction and international travel restriction, with Beta value of $\left(\beta_{=}-412, \beta_{=}-281\right.$ and $\left.\beta_{=}-044\right)$ all have significant negative relationship with the survival of SME businesses. Based on the finding, the study recommended that more financial and social aids/stimuli should be provided for SMEs owners in order to keep them operational during and after the pandemic. The study also recommended that social, health and economic infrastructures such as public health system, social welfare programs and digital economy should be worked upon.

Keywords: Coranavirus, Coranavirus Disease, COVID-19, Pandemic, Economy, Small and Medium Enterprises. Copyright @ 2020: This is an open-access article distributed under the terms of the Creative Commons Attribution license which permits unrestricted use, distribution, and reproduction in any medium for non-commercial use (NonCommercial, or CC-BY-NC) provided the original author and source are credited.

\section{INTRODUCTION}

At early 2019, the concern of economists, policy makers, businesses and corporate bodies and other major stakeholders was the effects that the Trump-China trade war, the Russia-Saudi-Arabia oil war, BREXIT and other political and politico-economic grievances among countries are having or could have on global economy. Nobody had foreseen that the global economy would be disrupted by something entirely different. Hence, at late 2019, their worries changed from all these to the impact that the novel Corona Virus (COVID-19) could have on global economy and its possible spillovers. After its outbreak in Wuhan, China, the disease has spread across the world and its corollary results such as the disruption of economic activities of different sectors of the economy and loss of lives continue to follow it wherever it goes. As at $14^{\text {th }}$ of May, 2020, the total confirmed cases stood at four million, three-hundred sixty-nine thousand, fourhundred and ten $(4,369,410)$ and total number of deaths stood at 297, 569, globally, CNN, 2020 while businesses are already shut down.

In Nigeria, as noted by Ozili [1] the economic decline was caused by the combinatory forces of decline in oil price and the Covid-19 outbreak which then led to a fall in the demand for oil products and pending of economic activities from taking place when social distancing and other restrictions were enforced in the country. Just like other countries, many sectors such as tourism, entertainment, sport, aviation, education, banking sectors are grossly affected by these restrictions [2]. Small and Medium Enterprises (SMEs) make up about $95 \%$ of the Nigeria economy and they serve as a source of employment generation, innovation, competition, economic dynamism which ultimately leads to poverty alleviation and national growth [3]. Because they enjoy a wider geographical presence than big companies, SMEs also contribute to better income distribution [4].

In this, the Small and Medium Enterprises are not exempted. Since, Small and Medium Enterprises play a crucial role in the economic wellbeing of countries in general and Nigeria in particular, this article examines the effects of the global pandemic, COVID-19, on the survival of businesses among SMEs in Ogun State, Nigeria. The article begins with a description of COVID-19, first, from a global perspective then to a Nigerian perspective, discussing the various sectors affected by it and the various measures that have been adopted and policy formulated 
to alleviate its adverse effects on various levels. The article then discusses the study's methodology, analysis, conclusion and recommendation consecutively.

\section{LITERATURE REVIEW \\ COVID-19 Pandemic: An Overview}

Declared a pandemic by the World Health Organization (WHO) on 11 March 2020, COVID-19 has become a global emergency, given its impact on the entire world population and the economy. As observed by Mohammad, Ashikul and Shikha [5] Coronavirus is considered one of the most infectious diseases which mainly occur after contaminating the human with the rigorous acute syndrome of respiratory issues. The particular disease has been evolved into a pandemic public health crisis because of extensive spread within nations. Beyond its impact on human health, COVID19 is disrupting an interconnected world economy through global value chains causing abrupt falls in commodity prices, fiscal revenues, foreign exchange receipts, foreign financial flows, travel restrictions, declining of tourism and hotels, frozen labour market, etc. [6].

\section{The Effect of the COVID-19 Pandemic on Global Economy}

At the beginning of their study, Ozili and Arun [7] asked two fundamental questions: how did a health crisis translate to an economic crisis? And why did the spread of the coronavirus bring the global economy to its knees? The authors' answers to the question lay in two methods: first, the spread of the virus brought about the introduction of the social-distancing measure and this led to the shutting down of financial markets, corporate offices, businesses and events, since people could not carry out financial and economic activities at close proximity. Second, the exponential rate at which the virus was spreading led to flight to safety in consumption and investment among consumers, investors and international trade partners, consequently affecting the wellbeing of the economy [7].

The European Union, the United States and Japan account for half of the world's GDP and these economies are based on trade, services and industries. However, measures to halt the pandemic have forced them to close their borders and drastically reduce economic activities; which will lead to recession in some of these developed economies. The Chinese economy accounts for about $16 \%$ of global GDP and it is the largest trading partner of most African countries and the rest of the world. The OECD forecasts a decline in economic growth rates for these major economies as follows: China $4.9 \%$ instead of $5.7 \%$, Europe $0.8 \%$ instead of $1.1 \%$, the rest of the world $2.4 \%$ instead $2.9 \%$, with world GDP falling by 0.412 from the first quarter of 2020. UNCTAD forecasts downward pressure on foreign direct investment from $-5 \%$ to $15 \%[2]$.
Moreover, before the emergence of the pandemic, the International Monetary Fund (IMF) made a projection of $3.4 \%$ global economy growth. However due to the pandemic, the IMF downgraded its growth projection for the global economy [8]. Moreover, due to the panic and the rational assessment by investors that firms' profits are likely to be negatively impacted of COVID-19, global stock markets lost about US\$6 trillion in one week from 24th to 28th of February while S\&P 500 index lost over $\$ 5$ trillion in value in the same week in the US and the S\&P 500's largest companies had a combined loss of over $\$ 1.4$ trillion (Reuters.com).

Noting the effect of the pandemic on tourism, Financial Times [9] observes that the tourism industry was affected as the travel opportunities for Chinese tourists, who usually spend billions annually, were severely curtailed and there were increased flight cancellations, cancelled hotel bookings and cancelled local and international events worth over \$200billion. Aviation industry revenues were $\$ 830$ billion in 2019 . These revenues were projected at $\$ 872$ billion in 2020 . As the number of new infections continues to surge in every part of the world, governments are working tirelessly to slow the contagion. Many countries have put a halt on long-distance. On 5th March 2020, the International Air Transport Association (IATA) has projected that Covid-19 could seriously disrupt the industry and cause a loss of about $\$ 113$ billion. This figure is underestimated as most countries are closing their borders and nobody knows when they will be reopened.

As noted by the African Union [2] the tourism industry is also facing challenges caused by the pandemic. According to the United Nations World Tourism Organization (UNWTO) there will be an expected fall of between $20-30 \%$ that could translate into a decline in international tourism receipts (exports) of between US\$300-450 billion, almost one third of the US\$ 1.5 trillion generated in 2019. Taking into consideration the past market trends, it shows that between five and seven years' worth of growth would be lost because of Coronavirus [10]. The unprecedented introduction of travel restrictions across the world, the international tourist arrivals will fall by $20 \%$ to $30 \%$ in 2020 when compared with 2019 figures. Many millions of jobs in the industry are at risk of being lost as around $80 \%$ of all tourism businesses are small and medium sized enterprises (SMEs).

Moreover, the pandemic also affected the global supply chain since the flow of goods reduced significantly, given that China was the world's largest manufacturer and exporter and the Chinese government had ordered the closure of major factories in the country. Other countries like Iran, Italy and France, etc issued stay-at-home nationwide policies to control the spread of the virus. Consequently, such policies made recession in developed countries imminent, and there 
was a general consensus among economists that the coronavirus pandemic would plunged the world into a global recession [9]. Based on this, the IMF has projected a global recession similar to that of 20072008 financial recessions with probable recovery in 2021.

\section{Global Responses to the Pandemic: Monetary and Fiscal Policies}

Globally, to combat the pandemic, various international institutions and countries have responded with different fiscal and monetary measures and policies. To start with the international bodies, the World Bank already prepared to deploy up to $\$ 160$ billion over the next 15 months to support COVID-19 measures that help countries respond to health consequences and bolster economic recovery; the IFC also provide $\$ 8$ billion to provide relief aid for private companies and employees affected by the pandemic; the IMF has released $\$ 50 \mathrm{bn}$ through its emergency financing facilities to help emerging economies that might require additional support; on its own end, The ECB governing council introduced a total sum of $€ 870$ billion towards its Pandemic Emergency Purchase programme, set up to support its member states while the AfDB launched its Fight COVID 19 Social Bond, which is a $\$ 3$ billion bond with a 3 -year maturity to reduce the impact of the pandemic on African countries [8].

As a response to the pandemic, the United Kingdom implemented the monetary policies of injecting $£ 200$ bn into the economy and also implemented a plan to pay $80 \%$ of wages up to $£ 2,500$ a month for workers who are out of work as a result of the pandemic. As a fiscal policy measure, the country's Bank of England has cut its interest rates to $0.1 \%$ from $0.25 \%$ to provide greater access to credit for individuals and businesses. The chancellor of the BoE also announced a £350bn package for loans and grants and a $£ 30$ bn injection into the economy as a means of boosting money supply [11]. In United State of America (USA) the government responded with a fiscal policy of implementing $\$ 8.3$ billion Coronavirus Preparedness and Response Supplemental Appropriations Act and and \$104 billion Families First Coronavirus Response Act which together provide $0.5 \%$ GDP for health care, sick leave, small business loans, and international assistance. Moreover, an agreement has also been reached on a US\$2 trillion stimulus bill (around 10\% of GDP). As a monetary policy, the Federal Reserve's is introduced a US\$700 billion Quantitative Easing program. The QE program is split between $\$ 500 \mathrm{bn}$ of Treasury bills and \$200bn of agency backed mortgage securities. In Canada, as a fiscal measure, about $\$ 52$ billion (2.3 percent of GDP) in given as direct aid to households, including payments to workers without sick leave, workers without access to employment insurance and an increase in existing GST tax credits and child care benefits. The country also injected 1.125 billion ( $0.05 \%$ of GDP) to the health system to support increased testing, vaccine development, medical supplies, mitigation efforts, etc and about $\$ 85$ billion (3.7\% of GDP) in direct support to businesses, including tax deferrals and wage subsidies. Canada monetary measures include reduction in its interest rates to $0.75 \%$ to increase access to cheaper loans for its citizens; lowered Domestic Stability Buffer by $12.5 \%$ to enable its deposit banks inject $\$ 300$ billion into the economy to boost money supply. In addition, the government has launched an insure mortgage purchase program to further boost liquidity in the market.

Germany's fiscal measures include a released of a $€ 156 \mathrm{bn}$ fiscal impulse to support small business owners who have been affected by the pandemic and to boost spending on its health sector; expansion of the volume and access to public loan guarantees for firms of different sizes, with an allocation of at least $€ 825$ billion ( $25 \%$ of GDP). Germany's monetary policy measures include the introduction of unlimited loans to businesses affected by the pandemic by reducing its interest rates to $0 \%$; and an additional $€ 100$ billion to refinance short-term liquidity provision to companies through its public development bank KfW. In China, the pandemic's country of origin, the government approved a sum of Y1.3 trillion to aid in the increased spending on disease prevention and control, production of medical equipment for the coronavirus and part of the fund is meant for its unemployment insurance and fiscal stimulus for individuals, as fiscal policy. As monetary policy measures, the Central bank reduced its reverse repurchase rates and its 1 year medium term lending facilities by 10 basis points to provide greater access to loans. In addition the apex bank also implemented a reserve cut rate of between $0.5 \%$ and $1 \%$ [12].

\section{COVID-19 Pandemic: The Nigerian Perspective}

The coronavirus entered Nigeria through an infected Italian citizen who came in contact with a Nigerian citizen who was subsequently infected with the coronavirus. The coronavirus then spread to other citizens in Lagos and to other parts of the country [1]. As at 16 May, 2020, the total confirm cases of COVID19 totalled 5,445 and the number of death due to COVID-19 summed 171. The COVID-19 pandemic has brought unprecedented challenges to economic activities in the country. Demand has fallen dramatically whilst some businesses either have shortages or are overwhelmed. In Nigeria, borders are being closed and changes are coming to the societies. As most parts of the country come under quarantine orders and consumers try to reduce human contact, business owners have come to recognise that their response to the pandemic will have a significant impact on the performance and ultimate survival of their businesses [7]. Regardless of their reactions however it is undeniable that the pandemic will have adverse 
effects on their businesses, most especially the owners of Small and Medium Enterprises in country.

Nigeria's dependence on Chinese imports has come to aggravate its vulnerability during this pandemic period. In 2019, raw materials constituted $70 \%$ of the total imports from China into Nigeria and according to the National Bureau of Statistics (NBS), Asia and Europe contributed $86 \%$ of Nigeria's imports in Q4 2019 [10]. The restrictions currently imposed on cross border trade have significantly distorted supply chains for business owners and are beginning to see the effect on the Nigerian economy. Business owners therefore need to be more agile, local and responsive to consumer needs, whether it be by increasing supplies or relying more on e-commerce. As opined by KPMG [10] agile organisations which can meet the needs of their consumers by localising their supply chains, offering a high degree of convenience and communicating clearly with their target market, will better ride through the crisis.

Ozili [1] opined that there are five main ways through which the Covid-19 pandemic spilled over into Nigeria. One, the Covid-19 pandemic affected customers' capacity to service loans. Consequently, this led to Non-Performing Loans and this depressed banks' earnings which in return eventually impaired banks' stability. Subsequently, banks were reluctant to lend as more and more borrowers struggled to repay the loans granted to them before the Covid-19 outbreak. Two, the most visible and immediate spill over was the drop in the price of crude oil, which dropped from nearly $\$ 60$ per barrel to as low as US\$30 per barrel in March. During the pandemic, people were no longer travelling and this led to a sustained fall in the demand for aviation fuel and automobile fuel which affected Nigeria's net oil revenue, and eventually affected Nigeria's foreign reserve. Three, there were supply shocks in the global supply chain as many importers shut down their factories and closed their borders. Nigeria was severely affected because Nigeria is an import-dependent country and as a result Nigeria witnessed shortage of crucial supplies like pharmaceutical supplies, spare parts, and finished goods from China. Four, the national budget was also affected: since the budget was formulated with the oil price at $\$ 57$ per barrel, however the decline in oil price led to adjustment in the national budget. Nigeria Stock Market was also affected. Major market indices in the stock market plunged when investors pulled out their investments into so-called safe havens like US Treasury bonds. Stock market investors lost over NGN2.3 trillion barely three weeks after the first case of coronavirus was confirmed and announced in Nigeria. The market capitalisation of listed equities, which was valued at NGN13.657 trillion (US\$35.2bn) on Friday, February 28, 2020 depreciated by NGN2.349 trillion to NGN11.308 trillion (US\$29.1bn) on Monday 23 March 2020. The All-share index closed at $21,700.98$ from
$26,216.46$ representing $4,515.48$ points or 20.8 per cent drop (Guardian.ng).

\section{Effect of the COVID-19 Pandemic on Nigerian Economy}

As shown by in the African Union Report (2020) Nigeria real GDP had decreased from $-1.58 \%$ in $2016,0.82 \%$ in $2017,1.93 \%$ in $2018,2.27 \%$ in 2019 to $-5 \%$ to $-10 \%$ in 2020 . The unemployment rate according to the source revealed that has increased from $14.3 \%$ in 2016 to 20.24 in 2017 to $23.13 \%$ as at 2018 to $28.65 \%$ in 2019 and $>35 \%$ in 2020 . Other further impacts projected by African Union include massive spike in employment, massive number of peoplein informal sector not earning daily wage between lockdown and recession, huge food security challenge, fiscal crisis at both FG and state level and depletion of external reserves [2].

On 16 March 2020, the Central Bank of Nigeria $(\mathrm{CBN})$ released a circular on its policy response to the outbreak to reflate the economy and support businesses. These measures include extension of one year moratorium on principal repayments effective March 1, 2020; reduction of interest rate on all CBN intervention facilities from 9 to 5 percent effective March 1, 2020; creation of a N50billion targeted credit facility for households and small- and medium-sized enterprises (SMEs) that have been particularly hard hit by COVID-19; creation of a credit support for healthcare industry; regulatory forbearance, and the strengthening of CBN Loan Deposit Ratio (LDR) [10]. Responses from banks and other institutions involve different measures to support their customers which include loan payment holiday, special waivers on payment of fees on credit cards, increasing credit card limits, short term support facilities and a waiver of charges on a specified number of transactions on digital platforms.

In response to the Covid-19 outbreak, the monetary authority, the Central bank, provided support in six ways. One, it granted extension of loan moratorium on principal repayments. This meant that any intervention loan currently under moratorium would be extended by one year. Two, it offered interest rate reduction on all intervention loan facilities from $9 \%$ to $5 \%$ beginning. Three, it offered a NGN50bn $(\$ 131.6 \mathrm{~m})$ targeted credit facility to hotels, airline service providers, health care merchants, among others. Four, it provided credit support to the healthcare industry to meet the increasing demand for healthcare services during the outbreak. The loan was available only to pharmaceutical companies and hospitals. Five, it provided regulatory forbearance to banks which allowed banks to temporarily restructure the tenor of existing loan within a specific time period particularly loans to the oil and gas, agricultural and manufacturing sectors. Six, it strengthened the loan to deposit ratio (LDR) policy which allowed banks to extend more 
credit to the economy. On the other hand, the fiscal authorities had to review and revise the 2020 national budget of N10.59 trillion (US\$28 billion). The government announced that the budget was reduced by NGN1.5 trillion ( $\$ 4.90$ billion) as part of the measures to respond to the impact of coronavirus on the economy and in response to the oil price crash. The new budget was benchmarked at US\$30 per barrel from US\$57 per barrel in the previous budget [1].

As opined by Ozili [1] some of the factors that have contributed to the severity of the pandemic in Nigerian context include poor public health infrastructure, weak and under-developed digital economy and lack of social welfare program. As it can be infer from the foregoing, the emergence of the novel pandemic of COVID-19 has brought about changes in economic activities; it has disrupt businesses and market. One major sector greatly affected by this pandemic is the SMEs sector; the pandemic has emerged as a threat to their survival. In other to examine the influence of the COVID-19 pandemic on SMEs survival, the following hypotheses are stated:

$\mathbf{H}_{\mathbf{0 1}}$ : The lockdown measure has no significant relationship with the survival of SMEs

$\mathbf{H}_{\mathbf{0 2}}$ : International travel restriction has no significant relationship with survival of SMEs
$\mathbf{H}_{\mathbf{0 3}}$ : Restriction of internal movement has no significant relationship with the survival of SMEs

\section{METHODOLOGY}

This study employed a survey research design. Survey design enabled the researcher to gather data from relatively large population from a representative sample of the population. Owners of SME businesses in Abeaokuta, Ogun State constituted the population of this study. According to Corporate Affair Commission (CAC), Ogun State [11] there are two-hundred and sixty one (261) registered SMEs in Abeokuta North Local Government. To determine the sample size for the study Yamane (1967) sample size formula $n=$ $\frac{\mathbf{N}}{\left(\mathbf{1}+\boldsymbol{N e}^{\mathbf{2}}\right)}$ was used. Where $\mathrm{n}=$ sample size, $\mathrm{N}=$ population size and $e=$ margin of error and $e=0.05$. Since we already known the total number of registered SMEs in Abeokuta, according to data from Corporate Affair Commission (CAC) Ogun State, to be 261, having applied the above formula, the sample size was calculated to be 158. Questionnaire was used as the research instrument for this study and the questionnaires were administered to SME owners during days allowed for free movement in the state. Correlation and linear regression analysis were used to help determine the nature of the relationship between the variables of the study.

\section{RESULTS AND DISCUSSION Model Summary}

\begin{tabular}{|c|l|c|c|c|c|}
\hline Model & $\mathbf{R}$ & R Square & Adjusted R $^{2}$ & Std. Error of the Estimate & Durbin Watson \\
\hline 1 & $.730^{\mathrm{a}}$ & .585 & .570 & 1.16375 & .756 \\
\hline
\end{tabular}

i. Predictors: (Constant), lockdown days, international travel restriction and internal movement restriction

ii. Dependent Variable: SMEs survival

From table, the study shows that independent variables combined with the dependent variable of 0.73 . The contribution of all independent variables to the dependent variable (SME survival) was by $\mathrm{R}$ Square 0.59. This indicates that factors combined explain the rate of $59 \%$ of the variation in SMEs survival is caused by lockdown days, international travel restriction and internal movement restriction which is considered as good percentage.

\begin{tabular}{|l|l|l|l|l|l|}
\hline Model & Sum of Square & Df & Mean Square & F & Sig \\
\hline Regression & 83.757 & 5 & 16.751 & 12.36 & $.003^{\mathrm{b}}$ \\
\hline Residual & 369.727 & 273 & 1.354 & & \\
\hline Total & 453.484 & 278 & & 12.36 & \\
\hline
\end{tabular}

a. Dependent Variable: SMEs Survival

b. Predictors: (Constant), Lockdown Days, International Travel Restriction and Internal Movement Restriction

\section{ANOVA}

Table shows the analysis of variance (ANOVA) for the model which shows the variability between the variables. This table reports an ANOVA which assess the overall significance of our model. It reports an F-statistic of 12.369 with a probability value of 0.00000 . Since the probability value of our model is less than the critical values of both 0.01 and0.05, it implies that the model is significant at both $1 \%$ and $5 \%$ level of significance and we can reasonably inferred that COVID-19 has a significant effect on survival of selected SMEs in Abeokuta, Ogun State. 


\section{Coefficients}

\begin{tabular}{|c|l|l|l|l|l|}
\hline \multirow{2}{*}{ Model } & \multicolumn{2}{|l|}{ Unstandardized Coefficients } & Std. Coefficients & \multirow{2}{*}{ t-Value } & \multirow{2}{*}{ Sig } \\
\cline { 2 - 5 } & $\mathbf{B}$ & Std. Error & Beta & & \\
\hline (Constant) & 4.444 & .358 & & 12.412 & .000 \\
\hline Lockdown Days & -.399 & .061 & -.412 & -6.598 & .000 \\
\hline International Travel Restriction. & -.384 & .082 & -.281 & -4.699 & .000 \\
\hline Internal Movement restricts. & -.213 & .019 & -.044 & .774 & .002 \\
\hline
\end{tabular}

The independent variables should be individually significant. This could be checked by using probability value of $t$-test. If the $\mathrm{p}$-value of $\mathrm{t}$-statistics is less than 5 percent $(0.05)$ then the null will be rejected and accept alternative hypothesis. If otherwise, the inverse will be the case. Lockdown days is statistically significant, since the p-value is 0.000 , this means that lockdown days has a significant effect on SMEs performance. International travel restriction is statistically significant, since the p value 0.000 , is less than 5percent level of significance. This means that it has a significant effect on SMEs survival in Ogun state. Internal movement restriction is also statistically significant; since the $\mathrm{p}$ value .002 is less than 5 percent level of significance. This analysis also shows that SMEs survival was negatively impacted by all subvariables of COVID-19.

\section{CONCLUSION AND RECOMMENDATION}

This study has assessed the influence of the COVID-19 pandemic on the survival of SMEs in Ogun -State, Nigeria. The results of the analysis unveiled that COVID-19 sub-variables like lockdown days, internal movement restriction and international travel restriction all have negative significant relationship with the survival of SME businesses in Ogun State, Nigeria. This finding is in line with the findings of Ganaie and Zafar [12] and Mohammad, Ashikul, Farzana, Mashrekha, AbuBakar and Huam [5] who also concluded that COVID-19 has negatively affected Small and Medium Enterprises in Pakistan and Malaysia respectively. Based on this conclusion, the study therefore recommended that more financial assistance/stimulus should be provided to SME businesses in order to keep them operational. It is also recommended that, since previous studies like Ozili [1] have identified poor infrastructural and structural factors has the secondary causes of the severity of the pandemic in the country, government should ensure that the country's public health system is improved, social welfare provided and digital economy is developed.

\section{REFERENCES}

1. Ozili P. Covid-19 pandemic and economic crisis: The Nigerian experience and structural causes. Working paper; 2020.

2. African Union. Impact of Corona Virus (COVID19) on African Economy;2020.

3. Ocheni SI. Impact analysis of tax policy and the performance of small and medium scale enterprises in the Nigerian economy. Strategic Management Quarterly.2015; 3: 71-94.

4. Adebisi JF and Gbegi, DO. Effect of multiple taxation on the performance of small and medium scale business enterprises. (A Study of West African Ceramics, Ajaokuta, Kogi State). Mediterranean Journal of Social Sciences.2013; 4(6), 323-334.

5. Mohammad H, Ashikul H, Farzana S, Mashrekha A, AbuBakar $\mathrm{H}$ and Huam, T. The Impact of Coronavirus (Covid-19) on E-Business in Malaysia. Asian Journal of Multidisciplinary Studies. 2020; 3(1),

6. AfDB. African Economic Outlook, Abidjan, Cote d'Tvoire; 2020.

7. Ozili PK and Arun TG. Spillover of COVID-19: impact on the Global Economy. Working paper; 2020.

8. Coopers P. Pharma. Challenging business models. Which path will you take? UK: PWC. 2009 Apr.

9. International Monetary Fund (IMF). Regional Economic Outlook (World economic and financial surveys), 0258-7440, Washington, D.C., U.S.A.2009.

10. https://cnn.com/cnn/2020/05/15/us/uscorononavirus-new-cases-rates-falling-and-risingthe-most/index.html

11. National Bureau of Statistics of China. Impact of Covid19 in the first two months, Beijing, China; 2020.

12. https://www.researchgate.net/figure/A-simplifiedformula-to-calculate-sample-size-Yamane1967_fig4_281629128

13. International Air Transport Association. Economics Chart of the Week, Havana, Cuba; 2020. 